\title{
THE CORRELATION BETWEEN SUSTAINABLE VALUE ADDED AND FINANCIAL PERFORMANCE AMONG INDONESIAN LISTED COMPANIES
}

\author{
Robertus Tedjobuwono, Eko Ganis Sukoharsono, and Erwin Saraswati \\ Accounting Department, Faculty of Economics and Business, University of Brawijaya
}

\begin{abstract}
Sustainability awareness is growing very fast in the society and companies. A lot of companies do Corporate Social Responsibility (CSR) to satisfy stakeholders, while in return they expect to get a better performance. This research discusses the correlation of sustainability performance to financial performance, by using sustainable value added as a mean of measurement. This measurement monetize the impact of environmental and society performance, so the performance can be measured precisely. This research uses Spearman Correlation to analyze the correlation of thirty-four samples. From this research, it is found that there is correlation between CSR and financial performance.
\end{abstract}

Keywords: Sustainability, Value Added, Financial Performance.

\section{INTRODUCTION}

In the growing awareness of the environment and social issues era, there are many ways to maximize profit. Increasing number of stakeholders shift their sight from getting what they can as soon as possible to getting what they want as long as the environment and social are sustain. They give a pressure, so companies allocate their resources to fulfill social expectations (Waddock and Graves, 1997). They also ask companies to be more transparent and expect more measurement, report, and continuous improvement to their social, environmental and economic performance. Smith (1759) stated that a capitalist system must be based on honesty and integrity, otherwise it will be destroyed. Adam Smith believed that self interest must be limited with ethics so the selfish behavior would not be the rule in the society (Dawson, 2004).

To promote the sustainability, WCED (1987) proposed sustainable development, "development that meets the needs of the present generation while letting future generations meets their own needs". Sustainability focuses on environmental protection (eco efficiency) as well as the people and generations. Penman and Zhang (2006) argued that investor, nowadays, buys an earning, that can be sustained. Though, the price of company share is increasing, the investor will not buy unless it will sustain. They believe that when the earth and society suffer, there will be no more profit. Moreover, Porter and Kramer (2006) stated that CSR is more than a cost; it can be the source of opportunity, innovation, and competitive advantage. This means the sustainability is the key for future success. This statement also supported by research done by Hillman and Keim (2001), which shows that stakeholder management, has a huge correlation in creating value. By managing stakeholder well, the company can create a competitive advantage that is not easy to be replicated.

Meanwhile, Indonesia, as a developing country, has a big role in supplying products to the globalization growing market. Indonesia with huge man power, in the last 20 years, has built a lot of factories, especially in Jakarta. In fact, these factories, today, is the main villain to the 
sustainability of the earth. Furthermore, each of the labors owns his/her own motorcycle and with its collaboration with the condition of infrastructure causes more pollution.

Like the rest of the world, there is also a growing awareness about sustainability in Indonesia. A lot of companies in Indonesia, today, implement a more sustainable approach in runningbusiness. They make a report to show what they have done to their environment, what they do to sustain the environment.

However, according to Hertwich (2005), a report or sustaining activity does not mean that the world will be really sustained. There is a rebound effect of doing sustainable activities. It explains the efficient companies might perform efficiently, but on the other side, they or other companies might perform worse. Hertwich (2005) gave an example, when a company use less electricity to run the company, they will spend the fund on other activities that might be worse for the environment. On the other side, other companies, which are less efficient, will use more resources than before.

In the efficiency theory, efficiency considerations are used whenever desired and undesired aspects need to be balanced. There are two things that need to be considered when looking at efficiency; they are opportunity costs and risk-return ratios. The opportunity cost is a benefit of unrealized alternatives. In this case the opportunity cost is the natural capital cost (sustainability cost of capital) that needs to be compared among companies that own higher risk and risk free.

Looking on those opportunity cost caused by the rebound effect, Figge and Hahn (2005) suggested that people should not focus only on the report and the activities the companies have done. There is not any empirical study that shows whether sustainability activities reported on the CSR gives a benefit to the environment as a whole. They must look, whether what the companies have created a value added to the environment. AsCallan and Thomas (2009) suggested that there is a need to do more researches to find the best measurement for sustainability performance. Figge and Hahn (2005) introduce the concept of sustainable value added. Sustainable value added is a concept that is meant to show how much value (e.g. profit) the company can get by using resources in the monetary term. This concept uses a benchmarking strategy. By doing this, the companies are compared to the countries where they operate.

After finding companies' sustainability performance, it is important to know the company's financial performance. As Porter and Kramer (2006) stated that CSR is more than a cost, it can be the source of opportunity, innovation, and competitive advantage, a company with good sustainability performance will tend to have a better financial performance as it is not easy to imitate. If the research shows that a company with a better sustainability performance has a better financial performance, the other companies will try to emulate this strategy, which indirectly will help the environment.

Though, there are a lot of studies about the relation between CSR and financial performances. However, there is a few researchers have done social responsibility research using monetary terms. It might be caused by the difficulties in finding the required data.

The objective of this research is to show how to calculate sustainability cost of capital and how the sustainability performance correlates with financial performance. Sustainability cost of capital will show how much pollution that a company does. On the hand, the correlation will show whether a good sustainability performance will boost financial performance or not. 


\section{LITERATURE REVIEW AND RESEARCH MODEL DEVELOPMENT}

The literatures that are going to be reviewed consist of the theoretical review and empirical reviews. The theoretical reviews will focus on how the concept of sustainability cost of capital and the sustainability value creation are found. On the other hand, the empirical theories will discuss how the descriptive concepts are applied on the real case.

\section{Eco-Efficiency}

World Business Council for Sustainable Development (WBCSD) described ecoefficiency as

"Being achieved by the delivery of competitively priced goods and services that satisfy human needs and bring quality of life, while progressively reducing ecological impacts and resource intensity throughout the life cycle, to a level at least in line with the Earth's estimated carrying capacity."

According to this theory, there are four elements of environment that has to be synchronized together; they are environmental impact (I), population (P), affluence (A) and technology $(\mathrm{T})$. This theory mentions that eco-efficiency is about balancing economic and environment. It is a ratio of economic value added to some measure of environmental impact.

According to Ehrenfeld (2005), it is not that difficult to determine the economic value added. The measurement of environmental impact; however, is quite challenging. It is very debatable to what elements should be put in and how it should be computed. The issue should be resolved in case-to-case scenario where each scenario is different to each other. However, there are three main steps that can be used; they are:

1. Choosing among alternative processes and products

2. Evaluating the performance of a company or other organizational entity

3. Evaluating the performance of a country, region or other macro entity

Eco - efficiency in this paper will be measured using Eco - Efficiency Indicators provided by United Nations Conference on Trade and Development (UNCTD), which is suggested by Figgie and Hahn (2005). In this standard, environmental impacts are described as CO2, N2O, $\mathrm{CH} 4$, working accident, and etc. These environmental impacts are also identified in world conference held in Kyoto, which is famously known as Kyoto Protocol.

\section{Rebound Effect (Herring and Roy, 2002)}

In the case of Eco - Efficiency, there are also a lot of discussion related to the rebound effect. While managing the level of environmental efficiency, sometimes, there is a rebound of it. It means that a company might use less certain resources / energy to produce a product, but on the other end, the company uses other resources as a substitution. For example, Toyota built a green car like Prius. Prius, for a customer, might be seen a green car because it uses less petrol than other cars. However, in reality, to produce this car, Toyota needs to carry the components from China and also uses a technology that makes a high pollution (Williams, 2009). Another example is wind turbines. Wind turbines are developed to create a renewable resource. However, to create these machines, the producer needs to use a heavy rare earths material, like dysprosium and terbium (Bradsher, 2009). This subchapter is dedicated to elaborate what the rebound effect is, the concept of it, and the relation with the topic discussed. 
Berkhout, Muskens, and Velthuijsen (2000) defined rebound effect using ceteris paribus assumption. Technological development has pushed more efficient equipment, which means less energy used to produce the same amount of results. As the equipment becomes more efficient, the cost per unit of energy falls. The falling cost usually tends to boost more energy consumption. This lost part of the energy conservation is defined as a rebound effect.

\section{Sustainability Development}

Companies are the main contributors to economic, social and environmental well being (Bennet, Burrit, \&Schaltegger, 2006). From this statement, it is believed that every activity done by companies in the present will be very critical for the future. In that case, it is necessary for the company to look for the company sustainability. Every activity is an investment for long term sustainable development of the economy, society, and environment. There are number of theories explain the growing awareness of support the perspective of sustainability development. Two of the theories that try to explain this issue are legitimacy and stakeholders theories:

\section{Legitimacy Theory}

Legitimacy was defined as a generalized perception or assumption that the actions of an entity are desirable, proper, or appropriate within some socially constructed system of norms, values, belief and definitions." (Suchman, 1995)According to Tilling (2004), there are two types of legitimacy theory. They are the 'macro theory' of legitimacy theory, Institutional Legitimacy Theory and organizational level of legitimacy theory, Strategic Legitimacy Theory. Most of the accounting researches use organizational level of legitimacy theory to gain an understanding of legitimacy and to link sustainability values added to its financial performance.

Mathews (1993) described legitimacy in organizational level as an organization tries to satisfy or to fulfill the social values and norms applicable in where they run their activies. Unless they can fulfill the disparity, there will be a threat to organizational legitimacy. Suchman (1995) explains that legitimacy is a resource, that is required by a business to run operation. So the company needs to have a high legitimacy position to be able to operate.Failing in doing such an activity will make the company branded as not legit and will affect the support from the community to the company.

\section{Stakeholder Theory}

In accounting literature, stakeholder theory has been used widely, especially in the introduction of corporate social reporting practice. Meek and Gray (1988) discussed that this kind of reporting is practiced to give more value to stakeholders, which is useful in attracting attention on wider group stakeholders. Rahman (1990) in his research found out that multinational companies prepare local host financial report to give a value to the dominant local stakeholders. In 1992 Roberts also found that amount of disclosure is influenced by stakeholder power, strategic structure and financial performance. On the same year, Rubenstein (1992) spilled out that as the firm has a social contract with stakeholders, companies need to include the natural assets account to determine the sustainability. In Woods and Ross research (2006), they discussed that stakeholders opinion have strong influences on manager attitude towards corporate social reporting. These researches show that there is a pressure in social and environmental reporting practices.

Stakeholder is a system which explicitly bases on the organization or environmental perspective that acknowledges complex and dynamic influencing characteristic between those two. The relationship between two parties is responsibility and accountability. Thus, organization 
has accountability to stakeholder. Also, according to Chand (2011), a management will tend to focus on how to satisfy the expectation of a strongest stakeholder. The strongest stakeholder in this perspective is the one who control the scarce and worth resources to achieve the objectives of company. From this perspective, every company will see the strongest stakeholder is the one who has the most potential to influence the ability of company to balance the stakeholders and maximize the profit. One of a strategy to keep the relationship with stakeholders is by preparing sustainability report to give information about economy, social, and environmental related to the company's activities. By preparing the report, it is expected that company can fulfill information required by stakeholders and get the support from the stakeholders.

\section{Benefits}

According to UNEP Finance Initiative (2005), there are several benefits of having sustainability practices, Firstly, revenue growth. It can be used to develop new products and services and as the result, increasing the revenue of the company. By launching new products, it gives the company a new competitive advantage in new market. Other than that, it can enhance the company reputation in society. It can also motivate other businesses to follow socioenvironmental move. Secondly, it is useful for risk managements. With changing regulations and expectations of social responsibility for businesses, sustainability development can be used to plot some risks that may affect companies and managing it. Sustainability development should help companies to create more sustainable environment to face the fluctuation in the industry. By doing so, the companies are benefited with risk management. Thirdly, many companies found it helpful to boost the companies' reputation in the market. In younger generations, companies with good practices are more attractive to investors. They believe a company who work ethically both for society and environment will have a more sustainable business. Financial and investment analyst found companies having lower environmental impact outperform market stock. Finally, by applying more sustainable practices, companies will find better ways to do their activities as it increases effectiveness and efficiency. Planned and organized application in all company divisions will lead to better-managed organizations. This will lead to a better efficiency in operational process, which ultimately will reduce the cost.

\section{Opportunity Cost}

Opportunity cost is defined as the cost of an alternative that must be forgone in order to pursue a certain action. It also could be described as a difference in return between a chosen investment and one that is necessarily passed up. In the sustainability area, opportunity cost could be defined not only as time and strength, but also commodities, capital, and many of the free gifts of nature, such as mineral deposits and the use of fruit- full land, must be economized if we are to act reasonably. Before devoting any one of these resources to a particular use, we must consider the other uses from which it will be withheld by our action; and the most advantageous opportunity which we deliberately forego constitutes a sacrifice for which we must expect at least an equivalent return. (Green, 1894, p. 224).

Possession of a capital constitutes an opportunity of some kind, which the company is unwilling to forego without adequate reward. A country, which owns the land (capital), should not forego their opportunity without reasonable reward. The company must guarantee the sustainability of the country. As good opportunities are limited in number and extent, devoting the opportunity to a particular activity, it behooves people (country) to consider from what other uses. Green (1894) stated the sacrifices of opportunity, which determine the expenses of production, must be explained upon the side of utility. 


\section{Cost of Capital}

Certified Management Accountant (CMA) described cost of capital as the combination rate of return required by both lenders and shareholders. It is the minimum acceptable return on economic investment as a cut off rate required for value creation. Lenders and shareholders require this cost as a consideration for their risk they bear. In that point of view, the cost of capital drivers talks about the tradeoff between risk and reward. The greater the risk is, the greater the required return and the cost of capital.

Cost of capital indicates value that would have been created by an alternative use of capital. Cost of capital is also normally called as opportunity costs. Green (1984) describes opportunity costs as the value fore gone by choosing a certain action.

$$
C C=\frac{V C^{M}}{C E^{M}}
$$

With $\mathrm{CC}$ being the cost of capital, $\mathrm{VC}^{\mathrm{M}}$ the value created by the market, and $\mathrm{CE}^{\mathrm{M}}$ the amount of capital employed by the market. Market Cost of Capital (CC) is an opportunity cost of the company.

A company creates value when it uses capital more efficiently than the market.

$$
V S=\frac{V C^{C}}{C E^{C}}-\frac{V C^{M}}{C E^{M}}
$$

with VS being the value spread, $\mathrm{VC}^{\mathrm{C}}$ the value created by the company, and $\mathrm{CE}^{\mathrm{C}}$ the amount of capital employed by the company.

\section{Cost of Debt}

Cost of debt exists because the company uses the debt financing. Debt financing nowadays plays a big role in the company success, as it will help the growth of the company. Goss and Roberts (2009) documents that the size of global syndicated loan markets is about four and a half times larger than the equity markets. According to Ross et al (2011), cost of debt is the return that lenders require on the firm's debt. It is the interest rate that the firm has to pay to the creditor on the borrowing. It is affected by the risk free rate return, maturity date, coupon rate, the probability of default, and etc.

From the above description of debt security returns, there are risks faced by lenders, fulfilling obligations problems and bankruptcy. It means the cost of debt reflects the probability of default and expected loss caused by the default. Sengupta (1998) argues that firms producing high quality disclosures are perceived to have a lower likelihood of withholding valuable unfavorable information, thus usually enjoy a lower cost of debt.

\section{Cost of Equity}

On the other hand, according to Ross et al (2011), cost of equity is the return that equity investors require on their investment in the firm. Using portfolio theory, Capital Asset Pricing Model (CAPM) suggests that the systematic component of a company's stock return is a proxy for the required return of equity. Although risks that are company-specific could be diversified away, certain company-specific characteristics still affect required return of equity.

\section{Cost of Sustainability Capital}

While cost of capital is a an opportunity cost from investment point of view, Cost of Sustainability Capital is an opportunity cost of financial market that is applied on other forms of 
capital as required by normative concept of sustainable development. Figge and Hahn (2005) interpreted the average value created by a form of capital in the market as its opportunity cost.

Thus, the opportunity cost of different forms of capital corresponds to the efficiency of the use of these different forms of capital on the level of benchmark. As mentioned by Figge and Hahn (2005), the concept of sustainability value used the ratio of the value created on the level of the entire economy per capital used as the opportunity cost. It is the minimum acceptable return on economic investment as a cut off rate required for sustainability value creation. Stakeholders require this cost as a consideration for their risk they bear. From this perspective, the sustainability cost of capital drivers talks about the tradeoff between environmental risk and reward. The greater the risk that the environment will not sustain the greater the required return needed.

The opportunity cost is determined by formula:

$$
\mathrm{CC}=\mathrm{VC}^{\mathrm{M}} / \mathrm{CE}^{\mathrm{M}}
$$

With $\mathrm{CC}$ is the cost of capital, $\mathrm{VC}^{\mathrm{M}}$ is the value created by the market and $\mathrm{CE}^{\mathrm{M}}$ is the amount of capital employed by the market.

In the financial market, profit is defined as indicator for value created. A value is created when a firm creates more than what the market makes. For that purpose, the yield of company and the market will be compared, this is called value spread.

$$
\mathrm{VS}=\mathrm{VC}^{\mathrm{C}} / \mathrm{CE}^{\mathrm{C}}-\mathrm{VC}^{\mathrm{M}} / \mathrm{CE}^{\mathrm{M}}
$$

With VS as value spread, $\mathrm{VC}^{\mathrm{C}}$ as the value created by the company and $\mathrm{CE}^{\mathrm{C}}$ as the amount of capital employed by the company.

The value spread shows how much value is created per unit of capital employed. Then, economic value created can be estimated by multiplying value spread and the amount of capital employed.

$$
\mathrm{OCC}_{i}=\frac{\mathrm{NDP}}{\mathrm{C}_{i}^{\mathrm{E}}}
$$

As $\mathrm{OCC}_{\mathrm{i}}$ equals opportunity cost of capital $\mathrm{i}$, NDP equals net domestic product and $\mathrm{C}^{\mathrm{E}}$ as amount of capital I used in the economy.

Then, we have all these companies in the country who is also creating value with their given level of capital, so we have:

$$
\mathrm{RC}_{i}=\frac{\text { NVA }}{\mathrm{C}_{i}^{\mathrm{C}}}
$$

With $\mathrm{RC}_{\mathrm{i}}$ equals return on capital $\mathrm{i}, \mathrm{NVA}$ as net value added for all economic entities and $\mathrm{C}_{\mathrm{i}}{ }_{\mathrm{i}}$ as amount of capital I used in the company.

Value is created when it exceed the opportunity cost of capital. This creates value spread:

$$
\mathrm{VS}_{i}=\frac{\mathrm{NVA}}{\mathrm{C}_{i}^{\mathrm{C}}}-\frac{\mathrm{NDP}}{\mathrm{C}_{i}^{\mathrm{E}}}
$$

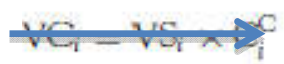


This means that we can also calculate the value spread of each capital by multiplying the value spread of each form of capital by the amount of capital used by the company.

Now that we have the value of VCi, we can determine the sustainable value (SV) created by dividing the sum of $\mathrm{VCi}$ by the number of capital that a company has.

$$
\mathrm{SV}=\frac{1}{n} \sum_{i=1}^{n} \mathrm{VC}_{i}
$$

It has to be noted that it might not be the best interpretation that we have all capital with same weights. Each capital would have different weights in a company's portfolio. However, this is only be used to imply that there is no double counting for each capital.

The next step is determining the sustainable efficiency of capital use. Basically sustainable efficiency of capital use is obtained by dividing NVA and the Cost of Sustainable Capital. We can obtain CSC from NVA minus the SV that have been determined from previous calculation. The formula is:

$$
\mathrm{SE}^{\mathrm{C}}=\frac{\mathrm{NVA}}{\mathrm{CSC}}
$$

Where SEC equals the sustainability efficiency of the company and CSC is the cost of sustainability capital. A company is more efficient when the NVA exceeds the CSC.

\section{Economic Cost of Capital (Economic Value Added)}

Economic Value Added (EVA) is a tool used to manage financial performance. It shows the profits after all cost are calculated, including interest, taxes, and a charge for employed capital. It measures both profitability and the growth of a business. Furthermore, Lewis and Leavell (1995) discussed, to be the world classcompetitior for a new investors, companies must have the ability to attract the investors by creating more value to them. EVA in this case will help the companies a lot. The companies can identify which part create or destroy the investors' value. Often, companies forget to count the equity. They take the investors money for granted. There is a one concept described by Lewis and Leavell (1995),

"The value of economic profit reminds managers that they have not really made a profit until they have earned an economic return on the equity capital they use."

EVA brings the concept how to manage the capitals. EVA helps the company to identify the efficiency and effectiveness and make an action. AT\&T changed the operations units to lean operations units, sold unprofitable departments, etc by the help of EVA. Using EVA will change the perception and way of thinking of the executives. Instead of chasing the operating earnings, the executives will focus on how to manage the capital to earn more money with limited supply of capital.

Lewis and Leavell (1995) discussed that EVA has helps companies to increase the companies' value. Increasing value means that companies can earn greater return than creditors and shareholder require. Shawn Tully (1993) establishes in her article The Real Key to Creating Wealth, "Incredibly, most corporate groups, divisions, and departments have no idea how much capital they tie up or what costs, until the figure all this out, they can't know whether they're 
covering all their costs and adding value to a company". In that case, EVA considers not only the cost of borrowed capital that is stated in the income statement as the interest expense, it also includes the cost of equity capital. By considering these capital costs, the company can identify a company that does not only get high earnings but also a company that can create the value.

Lewis (1995) described capital as the net operating assets or a sum of debt, equity and equity equivalents. Net Operating Profit after Taxes (NOPAT) is the total profits from operations before goodwill amortization and other non economic charges, less cash taxes. EVA equals NOPAT less capital charge.

$$
\mathrm{EVC}=\mathrm{VS} * \mathrm{CE}^{\mathrm{C}}
$$

A company will create a positive EVC when the value of the VS is positive which means the value created by the company is bigger than the opportunity cost of the capital employed. Positive VS means that the value is also higher than what would have been obtained by investing with the same capital in other investment.

\section{Sustainability Value Added}

The Sustainability value added could be defined as residual value that remains after the return has been reduced by the sustainability cost done by the company. The concept of sustainability value added is developed and introduced by the Figge and Hahn in 2005. The concept itself came from the idea of eco efficiency that nowadays is very popular to asses corporate contributions to sustainability. However, regardless of its popularity, eco efficiency cannot compete with other business information. It is measured using a synthetic unit (eg. \$ per $\mathrm{CO}_{2}$ - equivalents) that are difficult to interpret. Figge and Hahn in 2005 tried to solve this problem by combining the notion of eco-efficiency and efficiency in economics sector.

In economics concept, efficiency is looked as a consideration what is wanted and not wanted, return and risk. When an investor decides to invest; he/ she needs to describe the relation of risk and return. It means he/ she needs to look at the opportunity cost that may arise when the investment takes place.

Sustainable Value Added uses the same concept of Economic Value Added. The difference is on the variable used. In EVA, the capital employed (CE) uses the actual capital used by the country. On the other hand, the capital employed used by SVA is a non financial capital, it uses a synthetic value.

As the variables used are different, the result is also different. The value spread in EVA is a real figure, while on the SVA the value spread is a difference between the return of sustainability capital of a company and the return of country's sustainability capital.

Lastly, the value added described is also different. In EVA, the value added is only a single figure. On the other hand, the value added in SVA is the combination of all value created by the company of using several types of sustainability capital. 
Table 1. Economic Cost of Capital VS Cost of Sustainability Capital and SVA

\begin{tabular}{|l|l|l|}
\hline & $\begin{array}{l}\text { Economic Cost of } \\
\text { Capital }\end{array}$ & $\begin{array}{l}\text { Cost of Sustainability } \\
\text { Capital and Sustainable } \\
\text { Value Creation (Added) }\end{array}$ \\
\hline Opportunity Cost & $C C=\frac{V C^{M}}{C E^{M}}$ & OCC $=\frac{N D P}{C_{i}^{E}}$ \\
\hline Value Spread & $V S=\frac{V C^{C}}{C E^{C}}-\frac{V C^{M}}{C E^{M}}$ & $V S=\frac{N V A}{C^{C}}-\frac{N D P}{C^{E}}$ \\
\hline $\begin{array}{l}\text { Value Added Value } \\
\text { Added }\end{array}$ & $E V C=V S x C E^{c}$ & $V C=V S x C^{C}$ \\
\hline
\end{tabular}

\section{Corporate Sustainability and Firm Value}

There is a question whether better corporate sustainability gives a better value for a firm or not. This question once answered by Brickley, Smith, \& Zimmerman (2002). They argued that a better sustainability performance will result on a better firm value. They mentioned that sustainability performance attract a lot of potential customers. They also believed that it creates a differentiation. Chami, Cosimano, \&Fullenkamp (2002) also discussed that unethical company will lose their current and potential customers and ethical reputation may create an intangible asset, which will affect the firm value indirectly. In short, a good understanding about ethical practices gives more value to the company than short term profit maximization (Brickley, Smith, \& Zimmerman, 2002).

There are some argumentations that sustainability compliance is expensive and will affect the return negatively. However, McLaren (2004) in his research argued that successful implementation of labor standards, environmental protection, human right; etc is very unlikely to result in negative financial performance. In fact, Reinhardt (1999) argued that sustainability performance may give an competitive advantage, like what Porter and Kramer (2006) said. There are some empirical studies that show corporate responsibility gives a financial benefit (Konar and Cohen, 1997)

\section{Financial Performance}

Measuring financial performance in environmental friendly cases is not an easy task. There are a lot of types of measurements available and there is not any surveys that can say which the best one is. Each measurements have their own implications (Hillman and Keim, 2001). According to Cochran and Wood (1984), financial performance could be defined into two categories, investor returns (market based measurements) and accounting returns (accounting measurement). Investor return (market based measurement) is a return required by the investors (shareholders). There are ratios related to this measurement. The famous one is price per share. This ratio was believed to be the best measurement until it was found that this figure is not the only investor return (Moskowitz,1972). Abbott and Monsen (1979) thought to add dividends to their measurement. The result was also not consistent. 
Perception of a firm's social responsibility changed in 1975 and a naive researcher examined only the period 1977-1979, it will conclude that CSR and financial performance are unrelated.Ingram (1978) tests a correlation between sustainability disclosure and financial performance while using control variable in risk and industry effect. Sample was split into subgroups.

On the other hand, there is an accounting based measurement. These measurements are pretty straight forward. They usually are ratios. There are ratios that are very well known, like ROE, ROA, assets turnover, etc. To generate these measurements, analysts can take the data through the published information. That is why most of the time; analysis to financial performance is measured using financial ratios. These ratios quantify liquidity, leverage, and company profitability. This financial performance analysis is a base for financial planning and a mean to monitor company's performance. Moreover, it encourages analysts and investors to know whether the company does better than other companies. Investors will focus on financial ratios to ease their job in evaluating the growth of companies. It means through a good financial ratios will attract investors to invest. Besides, banks also look on financial ratios to evaluate whether they could give a loan to companies or not and determine the amount, as these ratios show the capability of companies to pay the loan and interest. Moreover, these ratios are also used by managers to monitor the effectiveness and efficiency of the companies. They can look at how the company operates and compare to other companies.

\section{Types of Accounting Based Measurement}

\section{ROA - Profitability}

Bernard et al (2010) discussed that return on assets (ROA) is a ratio that is used to show how much profit that a company can get by using its assets.

\section{Net profit margin - operating management}

Net profit margin is used to show the profitability of company's operating activities. This measurement helps analyst to look how efficient a company operates. To assess this ratio, the data could be gathered through income statement.

\section{Gross Profit Margin - Operating Management}

The gross profit is a difference between sales and its cost of sales. This measurement indicates how much profit that a company can get by taking into account the direct cost only. There are two factors that may influence the gross margin, the price premium and the efficiency of production process.

\section{EBIT Margin - Operating Management}

According to Bernard (2010) EBIT margin is one of the most comprehensive ratio for measuring operating performance of a company, as it shows all operating policies and eliminates all of debt policy.

\section{Operating Working Capital - Investment management}

This ratio is used to look how good a company in managing the account receivable, inventory, and accounts payable. It is a good measurement to look whether the number of capital used is suitable for a certain kind of company, as the capital structure of companies will not be the same for each industry. 


\section{Financial Leverage}

This ratio is used to look how liquid a company is. Bernard (2010) discussed that having a high leverage is good as long as the cost of it is less than the return of investing the funds. However, if it is too high, it will signal that the company may have a financial distress. There are some ratios that is closely related to this measurement, like current ratio, quick ratio, cash ratio, etc.

\section{Return on Equity}

In measuring the financial performance, Return on Equity (ROE) could be said is the best option. Bernard et al (2010) suggests that Return on Equity (ROE) is a measurement for overall profitability. ROE is a comprehensive indicator of an organization's performance that provides an indication of how well managers are employing the funds invested by the organization's shareholders to generate return. It comprises net profit margins, return on assets, and leverage structure. Net profit margin shows how well the company reduces the cost. Return on assets shows how effective and efficient the company in using the asset is. The leverage structure shows how liquid the company is.

By calculating ROE, an analyst can gain an understanding of the return being generated by the business's operations on the equity capital provided by (ordinary) shareholders. That is why the net income must be adjusted with the preferred shareholders. If a company does not issue preference shares, this figure could be disregarded.

Mostly, the appropriate measurement for net income to use in ROE is the profit for the year. This figure is used because analyst is most interested in the total return performance that management has been able to earn for common shareholders.

\section{Residual Income}

Another accounting based measurement is residual income. It is a measurement that takes into account the firm's required rate of return by investing in a capital. In this measurement the company's profit is deducted by the value of the return that is needed by a company. This measurement is good in showing how much extra profit the company got by investing a capital.

\section{Tobin's Q}

Though, ROE is a very comprehensive measurement. There are a lot of researchers who are skeptical and literatures showing that accounting based measurements are full of flaws (George benston, 1985). Montgomery and Wenerfelt (1988) discussed that accounting rates of return are inaccurate as a result of differences in systematic risk, tax laws, accounting policies, and etc. These figures have a great chance to be different across industries. In other words, it is impossible to compare firm in a certain industry. Therefore, it was introduced Tobin's Q.

Tobin's Q is a measurement that was developed by James Tobin (1969). This measurement combines the market value and the accounting based value. It was defined as a capital market value divided by replacement value of its assets. The capital market value itself is a combination of equity market value and debt market value, while replacement cost of assets could be defined as a book value of total assets.

The market value is a better measurement compared to accounting based value. The market value implicitly uses a correct risk adjusted, which is good to eliminate distortion. Tobin (1969) believed that financial policies and events can affect the demand by changing the value of assets. Beside financial policies, there are other aspects that can change the evaluation, like 
expectations, risk, attitudes, etc. That is why market value is the best option as it will correct the value automatically.

$$
Q=\frac{\text { marketvalueofequity }+ \text { marketvalueofdebt }}{\text { bookvalueofreplacementcostofassets (totalassets) }}
$$

\section{THEORETICAL FRAMEWORK AND HYPHOTHESIS}

Stakeholder theory and legitimacy theory imply that having a better sustainable practices will increase the financial performance (figure 1).

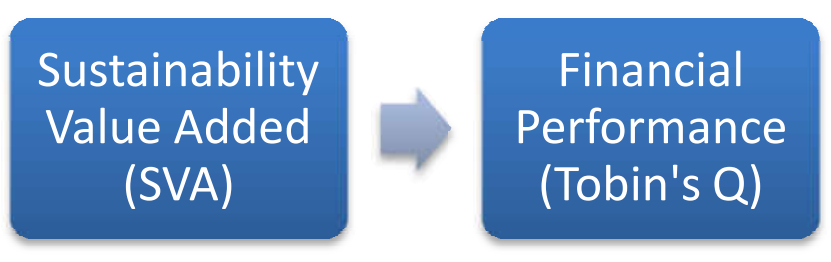

\section{Figure 1. Theoretical Framework}

Figge and Hahn (2005) introduced a sustainability value added, which monetize the sustainability performance. Figge and Hahn (2005) used the idea of eco-efficiency and economic value added. By using the opportunity cost concept, these two ideas could be combined to introduce the sustainability value added. In this thesis, the financial performance is represented by Tobin's Q. This measurement is chosen because of the value comprised in it. It integrates the accounting based value and market based value.

There are several empirical studies. Some of the studies show sustainability has a positive correlation on financial performance. There are also other researches showing a negative correlation and non correlation.

There are many researches showing a positive financial correlation given by sustainability. Saleh, Muhammad, and Zulkifli (2011) did a research about corporate social responsibility and company financial performance in the Malaysia from 1999 until 2005. Mittal, Sinha and Singh (2008) did their research of corporate social responsibility impact on financial report in India which found there is high demand of corporate social responsibility from a lot of stakeholder. Jo and Kim (2007) found the positive correlation too in Korea market. Azorin et al (2009) through literature review from 32 researchers also found the positive correlation. Lastly, Lo and Sheu (2007) found that sustainable practices increases firm value.

There are other researches showing the counter effect and inconclusiveness. Poddi and Vergalli (2009), by using417 international companies across the globe, from US, Europe, Japan, and etc. found that there is negative correlation between sustainability and market value added. Moreover, Li (2012) also found the same result with Poddi and Vergalli (2009). They use the data from 1999 to 2009 in 12 industries. They found that there is negative relation between total assets and CSR. Lastly, McWilliams and Siegel, 2001). On their research they found that there is no correlation between sustainability and financial performance. They believed that a company 
would choose the best option to maximize the profits. The company will judge their expenses on sustainability performance to the benefit that they will get.

$\mathrm{H}_{1}=$ Sustainable Value Added has a positive correlation on Financial Peformance.

\section{RESEARCH METHOD}

This research population is gathered from Indonesian listed companies that are listed in the Indonesian Stock Exchange (IDX) within 2012 - 2014. The data is selected within this period because that is the newest available data. By doing this, the data is expected to be relevant and reliable for nowadays situation.

Purposive sample can be used where the researcher judgment in selecting cases (samples) is very important. This technique will best enable the researcher to answer the research question and meet the objectives. According to Lewis, Saunders, and Thornhill (2005), purposive sampling is often used when working with very small samples that are particularly informative. The other reasons why purposive sampling is used are the data cannot be collected from the entire population, the research does not need statistical inferences, and the sample also does not need to be representative.

As what has been discussed above, this research is a new topic that there are not many researchers have done this topic, so there are not many research could be used as data or references. Moreover, there are not many companies that have prepared sustainability report, which is the most important data for this research. Even, the companies have the report, the report is not always useful for this research, as the data needed for this research is not always available.

Data criteria:

1. The data is available for public (could be accessed from company's website or other resources)

2. The company has the sustainability report

3. The sustainability report informs the consumption of $\mathrm{CO} 2$, working accidents, and company's fixed asset.

\section{Variables and Measurements}

To be able to analyze the correlation between sustainability performance and financial performance, there are two variables that are used in this research. The first one is the sustainable value added. The second one is Tobin's $Q$, the financial performance proxy.

First of all, sustainable value added is the variable used for measuring the sustainability performance. To be categorized as a good performance, company needs to beat the benchmark.

Sustainable value added calculation steps (Figure 2.):

Step 1. Determination of 'traditional' corporate eco-efficiency using return on capital (RC). The first step, eco - efficiency of company must determine. Figge and Hahn (2005) propose to use the ratio $\frac{\text { netvalueadded (return) }}{\text { EnvironmentalImpactAdded }}$.

Net Value added described by Figge and Hahn (2005) as a value created within a company after depreciation, excluding any value that has been created by suppliers or will be 
created by customers. In other words it comprises of EBIT and personnel expenses. The result of this assessment consequently show how much value is created with the emissions used for the owners, lenders, taxes, and employees. Net Value Added represents a company Net National Product of the country it is operating in. The sample of companies included in the assessment of Sustainable ValueCO2 with Net Value Added as a return figure is determined by the data availability concerning personnel expenses. When personnel expenses are not available, Barkemeyer et al (2011) suggest using EBIT.

Environmental impact added represents the sum of all energy and material used in operating activity weighted by the harmfulness to the environment. In this research the Environmental Impact Added consists of non-financial assets, $\mathrm{CO} 2$, and working accidents. This data is taken from environmental, sustainability, CSR and integrated reports.

Step 2. Determination of the 'traditional' eco-efficiency of the benchmark using opportunity cost of capital (OCC). The second step is defining the benchmark ratio as a comparison. As it is a benchmark, the equation must be the same with the ratio used.

Step 3. Calculation of a value spread $=\mathrm{RC}-\mathrm{OCC}$. To be able to compare the eco efficiency, the value spread is calculated. The value spread represents how much value added per unit of environmental impact added the company has produced compared to the benchmark.

Step 4. Calculation of the Environmental Value Added or Value Created (VC) = VS * Amount. In the last step, the level of environmental impacts of the company multiplies the value spread. It is done to make it easy to be interpreted. The result itself is called Environmental Value Added (Sustainability Value Added). It defines the much value added produced due to the fact that a given level of environmental impacts is used by the company instead of the benchmark.

Step 5. Total VC / Number of Variables used.

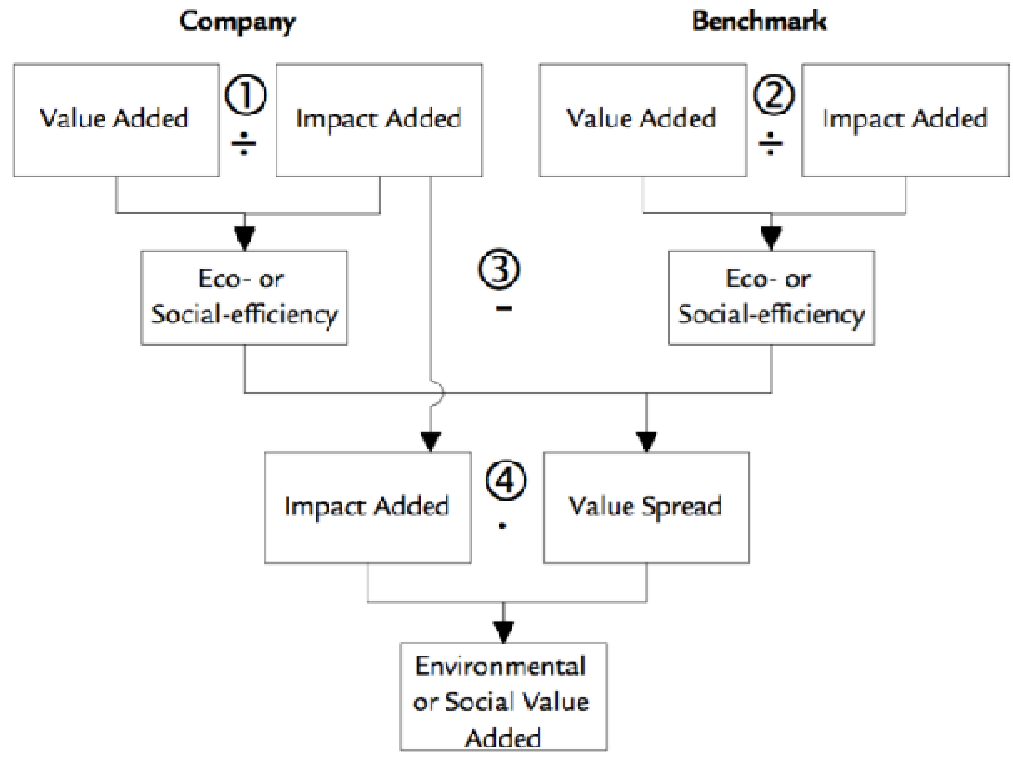

Figure 2. Sustainable Value Added Calculation Steps 
Moreover, Tobin's Q is used as a proxy for financial performance measurement. As what has been discussed the previous chapter, Tobin's Q is firm value. Higher Tobin's Q means a company has a higher firm value. This also means investors have a high expectation of company's financial performance. By analysing this variable, this research wants to know whether having a good sustainability performance is correlated with the financial performance (Tobin's Q).

\section{Analysis Technique}

This research is using SpearamanRank Analysis is suitable for this research. The first reason is because the data gathered cannot satisfy the classic assumptions, specifically normal distribution assumptions, which are required to be classified as parametric statistic. In that case, the data must be processed using non parametric statistic. Another reason is because the type of data is not nominal variable. Both of variables used in this research are ratio variable, which could be ranked. By doing this analysis, the research could find the correlation among variables, whether higher rank performs better too or not.

In Spearman Rank Analysis technique, there are several points that need to be considered to answer the hypothesis. They consist of Spearman Correlation Coefficient (Rs), $\mathrm{Z}$ value and significance. Spearman Correlation Coefficient is used to determine the direction of correlation and the strength of correlation, while the value determines the strength of the correlation. If the value is near to one (1), it means both variables are heavily correlated. When the value is near to zero, the variable is more likely to be neutral. Moreover, $Z$ value (1 tailed) is used to calculate the probability of a score within normal distribution and enable the researcher to compare. When the $\mathrm{Z}$ value is bigger than $\mathrm{Z}$ table, it means the probability of getting the same result is high. Lastly, the significance tells whether the research could reflect the population. When the significance below 0.05 , it means the result reflects the population.

\section{RESULT}

\section{Descriptive Statistic}

From the table 2 (Appendix A), it could describe that from thirty four data, the lowest value is - (minus) $1.068 .747,4$ and the highest is $12.092,23$. This figure shows that there is a company that decrease the sustainable value by Rp. $1.068 .747,4$ when it uses the resources. On the other hand, the is also a good company that can create a value to sustainability of Indonesia by Rp. 12.092,23. The next thing is the standard deviation; this figure explains that there is a lot of variation, as it is above $20 \%$. The most important thing is the mean. The mean of sustainability value added is -(minus) 84.748,93. This figure can tell that most of the companies who prepare an adequate sustainability report do not create a value. Most of them destroy the value.

Moreover, from the above table, it could be described that from the available data, the lowest financial performance (Tobin's Q) is .78 and the highest is 21.86. The figure explains that there is a company that has a value below its total asset and debt. There is also a company that has a value twenty one times its total asset and debt, which is very impressive. This figure is also far from the average. Though, there is one company that far from the others, the standard deviation is still below $20 \%$. 


\section{Spearman Rank Correlation Statistic}

This research is using Spearman Rank Correlation analysis technique. This analysis tool is used to measure the correlation between sustainable performance and financial performance. From the table 3 (Appendix A), there are several points that need to be discussed to describe the correlation of Sustainability Value Added and financial performance (Tobin's Q) They consist of Spearman Correlation Coefficient, Z Value, and Significancy (Sig. 1- tailed).

\section{Spearman Correlation Coefficient (Rs)}

The Spearman Correllation Coefficient (Rs) shows the strength and the direction of correlation. The result shows that this model has a correlation coefficient .390. This means that there is positive correlation. This figure explains that most of sample with higher sustainable performance tend to have a better financial performance. However, the strength of correlation is not strong, as the value near to zero (neutral). Collaborating with the descriptive statistic, the correlation analysis finding tells that, even though, most of the value are negative, the company with a better sustainable performance can achieve more profit.

\section{Z Value Analysis}

The $Z$ Value Analysis is used to ditermine the probability of the hyphothesis is rejected or accepted. In that case, the $Z$ Value must be calculated first and compared with the $Z$ Table value.

Z Value formula:

$$
\text { ZValue }=R s \sqrt{n-1}
$$

Rs: Spearman Correlation Coefficient

$\mathrm{n}$ : Number of Sample

Based on the above formula, with Correlation Coefficient $=0.390$ and thirty four (34) samples, the calculated $\mathrm{Z}$ Value is 2.24 .

With a degree of confidence $95 \%$ and significance of $5 \%$, the $Z$ table value for 1 tailed is 1.645 . By comparing the calculated $Z$ value and $Z$ table, it could be that the calculated $Z$ value is bigger than $Z$ table value $(2.24>1.645)$. This figure explains that the probability of having the same result is high. This high probability supports the Spearman Correlation Coefficient to confirm the hypothesis. 


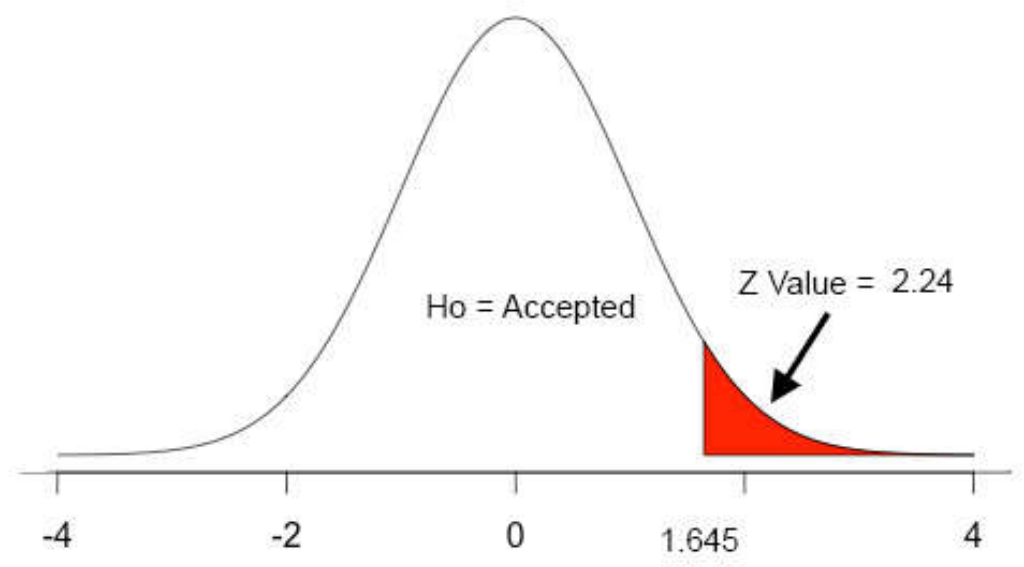

Figure 3. Z Value Diagram

\section{Significance (Sig. 1 Tailed)}

The last step is explaining the significance. This step is to test whether the result could represent the whole population. Lower significance means that the result could represent the population.

Hypothesis:

$\mathrm{H}_{1}=$ Coefficient Regression is significant.

In this research, the data process shows the result that SVA variable has a significance value below .05 (Sig.: .011). This figure supports the $\mathrm{Z}$ value analysis that the result could describe the population.

From the statistic process, it could be concluded that even though most of the samples generated show a negative sustainable performance, Sustainable Value Added has a correlation with the financial performance. It could be seen from the $Z$ value and significance. This finding confirms the theory and the hypothesis that there is positive correlation between sustainable performance and financial performance.

The result has been supported by previous studies, such as Saleh, Muhammad, and Zulkifli (2011), Mittal, Sinha and Singh (2008), and Jo and Kim (2007). On their research they found that there is a correlation between sustainability and financial performance. They also found that good sustainability performers have achieved their financial goal. Moreover, this research confirms that sustainability practice has been appreciated by stakeholders in Indonesia.

However, there is another point that needs to be considered. The strength of the correlation is not as strong as the correlation coefficient is not significantly far from the limit. The coefficient is below 0.5 , which means the correlation could be neutral. There might be some companies that have low financial performance though they have performed well on their CSR. The lower financial performers might be caused by the environmental and societal impact produced by the companies in using their resources. The companies use too much resource in order to generate their profit compared to Indonesia as a whole. Barnett and Salomon (2012) said that there is a possibility that sustainability may decrease the companies' profit as it depends on 
how good companies to capitalize their sustainability performance. Friedman (1970) also believed that sustainability activities will not help in increasing the financial performance; on the other hand it could be a source of expense. Lastly, some companies with worse performance are still new in preparing the report. Chami, Cosimano, \&Fullenkamp (2002) believe that some part of preparing is building a reputation. Reputation will not show in the short term. In that case, the new sustainability performer will not get the benefit of preparing the financial report.

\section{CONCLUSION AND IMPLICATIONS}

In conclusion, this research has found that, although there are many listed companies preparing the sustainability report and doing CSR, most of them do not create sustainable value added. Most of their return cannot cover the pollution that they have made. However, on the same time, this research confirms the hypothesis, companies with a better sustainability performance does have a better the financial performance. It means that a better sustainability performer have earned their reward by engaging a sustainable business, though, there might be some companies that are still trying to build their reputation.

From this research there are several implications. The first thing is this research can help the stakeholders in measuring the real sustainability performance. Furthermore, for a researcher, this research could help the future researchers to use this method in measuring the sustainability performance, which is more objective. In addition, as there is urgency about sustainability, it is believed that most of countries will enforce the sustainability activities. The government bodies can use this measurement as an alternative for a more objective measurement. Moreover, the world government needs to realize the importance of standardization. Sustainability is the world problem, so it is important to have one standard.Lastly, for all the stakeholders, this measurement helps to direct the focus of the stakeholders directly to the point as it is easier and straight forward. This measurement is like economic measurement that has a real value and can be measured. This is a faster way than using a subjectivity measurement to bring sustainability awareness to the people.

\section{LIMITATIONS AND SUGGESTIONS}

The main limitation is finding the sustainability report. As the sustainability reporting is still not a mandatory, there are not many companies that prepare the report voluntarily. Moreover, another limitation is the comparability. Though there might be up to thirty companies prepare the sustainability report, not many of them are really got an assurance from professional bodies. The last point is the time frame problem. This research only uses three years report. In fact, sustainability performance is not the same with financial performance. The change of sustainability policy will not affect the market simultaneously.

Because of those limitations, for further researchers who want to use the concept of Sustainable Value Added (SVA), there are several recommendations. The first one is using longer timeframe. As there is an article said that preparing a sustainability report is developing a reputation. Developing a reputation takes a longer time. Thus, longer the time can give a better understanding. This kind of research could be a time series research.Furthermore, it is suggested to use an assured sustainability report. In later years, researchers could expect that there will be more available data and available assurors. Lastly, as this research is processed using non parametric statistic, the next research may conduct the research using parametric statistic or 
Structural Equation Modeling (SEM) and compare the result. This research may give different result and different explanation to complete the sustainability references.

\section{REFERENCES}

Abbott, W. F., \&Monsen, R. (1979) On the measurement of corporate social responsibility: Selfreported disclosure as a measure of corporate social involvement. Academy of Management Journal, Vol: 22: 501- 515.

Azorin et al (2008) Quality Management, Environmental Management and Firm Performance: A Review of Empirical Studies and Issues of Integration. International Journal of Management Reviews.Vol.11(2).pp. 197-222.

Bennet, M., Burritt, R., \&Schaltegger, S. (2006) Sustainability accounting and reporting. Delft: Springer.

Benston G. J. (1985) The Validity of Profits- Structure Studies with Particular Reference to the FTC's Line of Business Data.American Economic Review: vol 75, pp 37-67.

Bernard et al (2010) Business analysis \& valuation: using financial statements. South Melbourne: Cengage Learning Australia.

Bradsher K. (2009) Earth - friendly elements, mined destructively. The New York Times.

Brickley, J. A., Smith, C. W. and Zimmerman, J. L. (2002) Business Ethics and Organizational Architecture, Journal of Banking and Finance, Vol: 26, 1821- 1835.

Cochran, P., \& Wood, R. (1984) Corporate social responsibility and financial performance.Academy of Management Journal, Vol. 27: 42-56.

Colle, S.E., Freeman, R.E., Harrison, J.S., Parmar, B.L. \& Wicks, A. C. (2010) Stakeholder theory: the state of the art.Cambridge University Press. New York.

Chami, R., Cosimano, T. F. and Fullenkamp, C. (2002) Managing Ethical Risk: how investing in ethics adds value, Journal of Banking and Finance, Vol: 26, 1697-1718.

Clarkson, P.M., Li, Y., Richardson, G.D. \&Vasvari, F.P. 2008. Revisiting the relation between environmental performance and environmental disclosure: An empirical analysis, Accounting, Organizations and Society, Vol. 33 (4), pp. 303-327.

Donaldson, T. and Preston, L. E. 1995. The stakeholder theory of the corporation: Concepts, evidence, and implications. Academy of Management Review 20 (1): 6591.

Ehrenfeld J.R. (2005) Eco - efficiency : philosophy, theory, and tools. Eco- efficiency and industrial ecology.Journal of Industrial Ecology.

Figge, F. and Hahn, T. (2005). Sustainable value added-Measuring corporate contributions to sustainability beyond eco-efficiency.Ecological Economics 48(2): 173-187.

Friedman, M. 1970.The social responsibility of business is to increase its profits, New York Times Magazine, September 13, pp. 122-126.

Goss A. and Roberts G. S. (2009) The impact of corporate social responsibility on the cost of bank loans.

Green, D. I. (1894). Pain-cost and opportunity-cost. The Quarterly Journal of Economics 8(2): 218-229.

Hamel, G. and Prahalad, C. K. (1994) Competing for the future: Breakthrough Strategies, Boston, MA: Harvard Business School Press.

Herring, Horace and Roy, Robin (2002) Sustainable services, electronic education and the rebound effect. Environmental Impact Assessment Review, 22(5), pp. 525-542.

Hertwich, E. G. (2005).Consumption and the rebound effect: An industrial ecology perspective. Journal of Industrial Ecology 9(1-2): 85-98. 
Hillman, A., \&Keim, G. (2001). Shareholder value, stakeholder management, and social issues: What's the bottom line? Strategic Management Journal, 22, 125-139.

Jo, H. and Kim, Y., (2007) Ethics and Disclosure: A Study of the Financial Performance of Firms in the Seasoned Equity Offerings Market.Journal of Business Ethics.Vol. 80 (4).pp. 855-878.

Ingram, R. W. (1978), An Investigation of the Information Content of (Certain) Social Responsibility Disclosures. Journal of Accounting Research Vol: 58(3), pp. 270-285.

Konar, S. and Cohen, M. A. (1997) Information as Regulation: the effect of community right to know laws on toxic emissions. Journal of Environ- mental Economics and Management.Vol: 32. 109-124.

Kramer, M. R and Porter, M. E. (2006) Strategy and society: the link between competitive advantage and corporate social responsibility. Harvard Business Review.

Lewis, R and Leavell, W. H. (1995) Economic value added, Working Paper : No. 96-17G.

Lewis, P., Saunders, M., \&Thornhill, A., (2009) Researh methods for business students. $5^{\text {th }}$ Edition, Harlow: Prentice Hall.

Li, S. (2012) Further evidence on the association between corporate social responsibility and financial performance, International Journal of Law and Management, Vol. 54(6), pp.472 $-484$.

Lo, S.F., and Sheu, H. J. (2007) Is corporate sustainability value - increasing strategy for business?. Journal compilation, Vol 15 (2), 345-358. Blackwell Publishing Ltd.

Mathews, M. R. (1993) Socially Responsible Accounting, UK, Chapman \& Hall.

McLaren, D. (2004) Global Stakeholders: corporate accountability and investor engagement, Corporate Governance - An International Review, Vol: 12, 191- 201.

McWilliams, A. \& Siegel, D. 2001. "Corporate social responsibility: A theory of the firm perspective", The Academy of Management Review, vol. 26, no. 1, pp. 117-127.

Meek, G. K. and Gray, S. J. 1988. The value added statement: An innovation for US companies?Accounting Horizons 2 (2): 7381.

Mittal, R.K., Sinha, N., Singh, A., (2008) An analysis of linkage between economic value added and corporate social responsibility, Management Decision, Vol. 46(9), pp.1437 - 1443.

Montgomery, C.A. and Wernerfelt, B. (1988) Tobin's $q$ and the importance of focus in firm performance. The American Economic Review, Vol.79: 1, pp. 246-250.

Moskowitz (1972) Choosing socially responsible stocks. Business and Society, Vol: 1: 71-75.

Poddi, L. and Vergalli, S. (2009) Does corporate social responsibility affect the performance of firms? University of Perugia.

Penman, S., and Zhang. X. (2006). Modeling sustainable earnings and P/E ratios with financial statement information. Unpublished paper, Columbia University and University of California, Berkeley.

Porter, M. 1980. Competitive Strategy. New York: Free Press.

Reinhardt, F. L. (1999) Bring the Environment Down to Earth, Harvard Business Review, Vol: $77,149-157$.

Ross, S.S et al (2011) Fundamental of corporate finance. McGraw Hill, North Ryde.

Saleh, M., Zulkifli, N. and Muhamad, R. (2011) Corporate social responsibility disclosure and its relation on institutional ownership: Evidence from public listed companies in Malaysia, Managerial Auditing Journal, Vol. 25(6), pp.591 - 613.

Schaltegger, S. and Sturm, A. (1989) Ecology induced management deci- sion support. Starting points for instrument formation. WWZ-Discussion Paper No. 8914. Basel, Switzerland: WWZ.

Sengupta, P. (1998) Corporate Disclosure Quality and the Cost of Debt. Accounting Review. 
112 The Correlation Between Sustainable Value Added.......

Smith, A. 1759 [1976]. The Theory of Moral Sentiments, edited by D.D. Raphael and A.L. Macfie. Oxford: Oxford University Press.

Suchman, M. C. (1995) Managing Legitimacy: Strategic and Institutional Approaches. Academy of Management Journal, Vol. 20, No. 3, pp. 571 - 610.

Rubenstein, D. B. 1992.Bridging the gap between great accounting and black ink. Accounting. Organizations and Society 17 (5): 501508.

Tilling, M. (2004), Communication at the Edge: Voluntary Social and Environmental Reporting in the Annual Report of a Legitimacy Threatened Corporation. APIRA Conference Proceedings, Singapore, July.

Tobin, J. (1969) A general equilibrium approach to monetary theory. Journal of Money. Credit and Banking. Vol 1(1).pp. 15-29.

Tully, S. (1993) The Real Key to Creating Wealth, Fortune: 123 - 132.

Waddock, S. A. and Graves, S. B. 1997. The corporate social performance-financial performance link. Strategic Management Journal, 18(4): 303-319.

WCED (World Commission on Environment and De- velopment). (1987). Our common future. New York: Oxford University Press.

Williams S. (2009) Toyota engineers flowers to offset production pollution, The New York Times.

Wood, D. and Ross, D.G. 2006. Environmental social controls and capital investments: Australian evidence. Accounting and Finance 46 (4): 677695. 


\section{APPENDIX A}

Table 2. Descriptive Statistic

Descriptive Statistics

\begin{tabular}{|l|r|r|r|r|r|}
\hline & \multicolumn{1}{|c|}{ N } & \multicolumn{1}{c|}{ Minimum } & Maximum & \multicolumn{1}{c|}{ Mean } & \multicolumn{1}{c|}{\begin{tabular}{c}
\multicolumn{1}{c}{ Std. } \\
Deviation
\end{tabular}} \\
\hline $\begin{array}{l}\text { SustainableValue } \\
\text { Added }\end{array}$ & 34 & -1068747.4 & 12092.23 & -84748.926 & 253319.819 \\
$\begin{array}{l}\text { FinancialPerform } \\
\text { ance }\end{array}$ & 34 & .78 & 21.86 & 3.1206 & 4.64396 \\
Valid N (listwise) & 34 & & & & \\
\hline
\end{tabular}

Table 3. Spearman Correlation Table

\section{Correlations}

\begin{tabular}{|c|c|c|c|c|}
\hline \multirow{7}{*}{ Spearman's rho } & & & SVA & Tobin \\
\hline & \multirow[t]{3}{*}{$\overline{\text { SVA }}$} & $\begin{array}{l}\text { Correlation } \\
\text { Coefficient }\end{array}$ & 1.000 & $.390^{*}$ \\
\hline & & Sig. (1-tailed) & . & .011 \\
\hline & & $\mathrm{N}$ & 34 & 34 \\
\hline & \multirow[t]{3}{*}{ Tobin } & $\begin{array}{l}\text { Correlation } \\
\text { Coefficient }\end{array}$ & $.390^{*}$ & 1.000 \\
\hline & & Sig. (1-tailed) & .011 & . \\
\hline & & $\mathrm{N}$ & 34 & 34 \\
\hline
\end{tabular}

*. Correlation is significant at the 0.05 level (1-tailed). 
114 The Correlation Between Sustainable Value Added.......

\section{APPENDIX B}

Table 4. SVA Table

\begin{tabular}{|c|c|c|c|c|c|}
\hline No. & Company & $\begin{array}{c}\text { NVA / } \\
\text { Asset } \\
\end{array}$ & $\begin{array}{c}\text { NVA / } \\
\text { Accident } \\
\end{array}$ & $\begin{array}{c}\text { NVA/Ton } \\
\text { CO2 } \\
\end{array}$ & $\begin{array}{c}\begin{array}{c}\text { Sustainable Value Added } \\
\text { (SVA) }\end{array} \\
\end{array}$ \\
\hline 1 & Astra & 0.54 & 0.635 & 0.0196 & $-1,061,653.35$ \\
\hline 2 & Astra2 & 0.59 & 43.690 & 0.0001 & $-1,068,747.42$ \\
\hline 3 & PGN & 0.43 & 34.731 & 0.0001 & $7,445.19$ \\
\hline 4 & PGN2 & 0.63 & 7461.487 & 0.2324 & $10,517.25$ \\
\hline 5 & ADARO1 & 0.41 & 8046.188 & 0.2947 & $-6,193.05$ \\
\hline 6 & ADARO2 & 0.57 & 25.167 & 0.0058 & $-1,897.23$ \\
\hline 7 & Danamon & 2.56 & 32.321 & 0.0085 & $5,856.02$ \\
\hline 8 & Danamon2 & 3.37 & 6368.503 & 5.7895 & $7,538.85$ \\
\hline 9 & APP & 0.04 & 8032.014 & 5.6168 & $-153,573.60$ \\
\hline 10 & APP2 & 0.05 & 177.454 & 0.0001 & $-143,514.21$ \\
\hline 11 & APP3 & 0.01 & 289.109 & 0.0002 & $-136,363.27$ \\
\hline 12 & Holcim1 & 0.12 & 149.450 & 0.0001 & $-37,415.87$ \\
\hline 13 & Holcim2 & 0.18 & 79.856 & 0.0003 & $-35,408.11$ \\
\hline 14 & Holcim3 & 0.31 & 92.814 & 0.0004 & $-34,208.03$ \\
\hline 15 & BII & 1.89 & 8.650 & 0.0006 & $1,964.35$ \\
\hline 16 & $\mathrm{BII} 2$ & 3.11 & 2223.171 & 0.7335 & $3,211.52$ \\
\hline 17 & $\begin{array}{l}\text { united } \\
\text { tractor1 }\end{array}$ & 0.58 & 3450.966 & 1.5700 & $-109,765.43$ \\
\hline 18 & $\begin{array}{l}\text { united } \\
\text { tractor2 }\end{array}$ & 0.53 & 33.811 & 0.0005 & $-111,297.58$ \\
\hline 19 & $\begin{array}{l}\text { Bank } \\
\text { Permata1 }\end{array}$ & 0.10 & 28.279 & 0.0004 & $-5,622.70$ \\
\hline 20 & $\begin{array}{l}\text { Bank } \\
\text { Permata2 }\end{array}$ & 0.11 & 4250.705 & 0.3138 & $-4,898.30$ \\
\hline 21 & $\begin{array}{l}\text { Indocement } \\
1\end{array}$ & 1.69 & 4312.627 & 0.3041 & $12,092.23$ \\
\hline 22 & $\begin{array}{l}\text { Indocement } \\
2\end{array}$ & 2.02 & 554.240 & 0.0226 & $10,989.90$ \\
\hline 23 & $\begin{array}{l}\text { Indocement } \\
3\end{array}$ & 2.08 & 223.496 & 0.0209 & $9,090.80$ \\
\hline 24 & Unilever1 & 1.05 & 158.471 & 0.0187 & $5,382.92$ \\
\hline 25 & Unilever2 & 1.04 & 7699.085 & 0.0610 & $4,988.75$ \\
\hline 26 & ITM & 1.10 & 7183.473 & 0.0587 & $-4,110.27$ \\
\hline 27 & ITM2 & 1.07 & 439.629 & 0.0037 & $-4,522.86$ \\
\hline 28 & ITM3 & 1.90 & 278.518 & 0.0037 & -552.65 \\
\hline 29 & Bukit Asam & 0.81 & 809.792 & 0.0068 & -356.74 \\
\hline
\end{tabular}

Vol. 25, No. 1 August 2017 
The International Journal of Accounting and Business Society

\begin{tabular}{|r|l|r|r|r|r|}
\hline No. & Company & \multicolumn{1}{c|}{$\begin{array}{c}\text { NVA / } \\
\text { Asset }\end{array}$} & \multicolumn{1}{c|}{$\begin{array}{c}\text { NVA / } \\
\text { Accident }\end{array}$} & \multicolumn{1}{c|}{$\begin{array}{c}\text { NVA/Ton } \\
\text { CO2 }\end{array}$} & $\begin{array}{c}\text { Sustainable Value Added } \\
\text { (SVA) }\end{array}$ \\
\hline 30 & $\begin{array}{l}\text { Bukit } \\
\text { Asam2 }\end{array}$ & 1.09 & 3231.725 & 0.0124 & $-1,478.54$ \\
\hline 31 & $\begin{array}{l}\text { Bukit } \\
\text { Asam3 }\end{array}$ & 2.43 & 3061.881 & 0.0068 & $3,065.27$ \\
\hline 32 & $\begin{array}{l}\text { Medco } \\
\text { Energy }\end{array}$ & 0.08 & 4512.632 & 0.0275 & $-7,527.93$ \\
\hline 33 & $\begin{array}{l}\text { Medco } \\
\text { Energy2 }\end{array}$ & 0.15 & 204.400 & 0.0034 & $-15,904.15$ \\
\hline 34 & $\begin{array}{l}\text { Medco } \\
\text { Energy3 }\end{array}$ & 0.14 & 346.780 & 0.0015 & $-18,595.24$ \\
\hline
\end{tabular}


116 The Correlation Between Sustainable Value Added.......

APPENDIX C

Table 5. SVA and Financial Performance (Tobin's Q) Table

\begin{tabular}{|c|c|c|c|c|}
\hline & & THN & $\begin{array}{l}\text { Sustainable } \\
\text { Value Added } \\
\text { (SVA) }\end{array}$ & $\begin{array}{l}\text { Fin. Performance } \\
\text { (Tobin's Q) }\end{array}$ \\
\hline 1 & Astra & 2014 & $-1,061,653.35$ & 1.96 \\
\hline 2 & Astra2 & 2013 & $-1,068,747.42$ & 1.90 \\
\hline 3 & PGN & 2014 & $7,445.19$ & 1.86 \\
\hline 4 & PGN2 & 2013 & $10,517.25$ & 2.44 \\
\hline 5 & ADARO1 & 2013 & $-6,193.05$ & 0.85 \\
\hline 6 & ADARO2 & 2012 & $-1,897.23$ & 0.89 \\
\hline 7 & Danamon & 2014 & $5,856.02$ & 1.08 \\
\hline 8 & Danamon2 & 2013 & $7,538.85$ & 1.06 \\
\hline 9 & APP & 2014 & $-153,573.60$ & 0.78 \\
\hline 10 & APP2 & 2013 & $-143,514.21$ & 0.89 \\
\hline 11 & APP3 & 2012 & $-136,363.27$ & 0.89 \\
\hline 12 & Holcim1 & 2014 & $-37,415.87$ & 3.22 \\
\hline 13 & Holcim2 & 2013 & $-35,408.11$ & 6.09 \\
\hline 14 & Holcim3 & 2012 & $-34,208.03$ & 9.38 \\
\hline 15 & BII & 2014 & $1,964.35$ & 0.99 \\
\hline 16 & $\mathrm{BII} 2$ & 2013 & $3,211.52$ & 1.05 \\
\hline 17 & united tractor 1 & 2014 & $-109,765.43$ & 1.71 \\
\hline 18 & united tractor2 & 2013 & $-111,297.58$ & 1.73 \\
\hline 19 & Bank Permata1 & 2014 & $-5,622.70$ & 1.01 \\
\hline 20 & Bank Permata2 & 2013 & $-4,898.30$ & 1.00 \\
\hline 21 & Indocement 1 & 2014 & $12,092.23$ & 2.94 \\
\hline 22 & Indocement 2 & 2013 & $10,989.90$ & 3.37 \\
\hline 23 & Indocement 3 & 2012 & $9,090.80$ & 3.92 \\
\hline 24 & Unilever1 & 2014 & $5,382.92$ & 21.86 \\
\hline 25 & Unilever2 & 2013 & $4,988.75$ & 18.23 \\
\hline 26 & ITM & 2014 & $-4,110.27$ & 1.36 \\
\hline 27 & ITM2 & 2013 & $-4,522.86$ & 1.80 \\
\hline 28 & ITM3 & 2012 & -552.65 & 2.31 \\
\hline 29 & Bukit Asam & 2014 & -356.74 & 1.99 \\
\hline 30 & Bukit Asam2 & 2013 & $-1,478.54$ & 2.09 \\
\hline 31 & Bukit Asam3 & 2012 & $3,065.27$ & 2.79 \\
\hline 32 & Medco Energy & 2014 & $-7,527.93$ & 0.93 \\
\hline
\end{tabular}

Vol. 25, No. 1 August 2017 


\begin{tabular}{|r|l|r|r|r|}
\hline & & THN & $\begin{array}{l}\text { Sustainable } \\
\text { Value Added } \\
\text { (SVA) }\end{array}$ & $\begin{array}{l}\text { Fin. Performance } \\
\text { (Tobin's Q) }\end{array}$ \\
\hline 33 & Medco Energy2 & 2013 & $-15,904.15$ & 0.90 \\
\hline 34 & Medco Energy3 & 2012 & $-18,595.24$ & 0.83 \\
\hline
\end{tabular}

